\title{
Selecting plant species for landfill revegetation: a test of 10 native species on reclaimed soils
}

\author{
Uhram Song (10
}

\begin{abstract}
Background: Revegetating landfills can be a challenging task as the reclaimed soils are typically dry and have low nutrient content. Therefore, selecting suitable plant species is important for initial revegetation. The issue with current practices (in Korea) is that alien plant species have been typically selected for revegetation projects. In this context, this study selects and tests a set of native plant species for landfill revegetation, accompanied by the assessment of the landfill soils.

Results: The soil of the landfill (landfill location) was in a very poor condition with high bulk density and low organic matter and nutrient contents. Among 10 tested species, only Brassica campestris showed high coverage and a sufficient number of individuals in study quadrats sown with seeds. Results suggest that plant species with heavy seeds are the only ones that can adapt to the environment of a typical landfill due to the site's aridity and low nutrient content. The reason is due to such species' superior wind resistance and the capacity to provide sufficient energy for the initial growth of the plants for survival in such landfill environment.
\end{abstract}

Conclusions: This study recommends selecting plant species (1) with arid-adapted features and (2) whose seed weight is sufficiently heavy for survival at landfills or areas with a similar condition for future revegetation.

Keywords: Landfill, Revegetation, Seed spray, Rapeseed, Reclaimed soil

\section{Background}

The progress of modern civilization and increase in population has driven an increase in the quantity and variety of waste generated (Anikwe and Nwobodo 2002). Sanitary landfills are one of the most widely used methods to dispose of such wastes worldwide (Johannessen and Boyer 1999). Constructing and managing landfills, however, still face many practical challenges including the management of the leachate (Kim and Lee 2005) and gas emission as well as the revegetation of the slopes (Gottinger 2018). As in the case of the Sudokwon Landfill in South Korea, the largest sanitary landfill in the world, it collects the soil for reclamation by digging up soils from adjacent areas up to $100 \mathrm{~m}$ depth. The resulting soil often has poor nutrient contents $(\sim 0.01 \%$ $\mathrm{N})$ and low moisture, which may limit plant growth

Correspondence: uhrami@gmail.com

Department of Biology and Research Institute for Basic Sciences, Jeju

National University, Jeju, South Korea
(Song and Lee 2010) after the waste reclamation. More problematic is that the soil often does not have existing seed bank that enables natural revegetation after reclamation. Previous studies on the Sudokwon Landfill found almost no seed inside the soil to restore vegetation to the Landfill site (Song 2010). Another natural revegetation process, seed dispersal from nearby areas, can be highly limited when the size of the landfill is very large.

Seed spraying, or seed sowing, has been performed for revegetation and refers to the application of seeds and supplementary materials (fertilizers and covering materials) for recently constructed areas including landfills (Shen et al. 2007). Seed spraying is a term popularly and almost exclusively used in East Asian scholarship to distinguish the application of seeds only (seed sowing) from a popular revegetation practice of applying both seeds and supplementary materials to promote initial growth (seed spraying). This study follows this distinction and will refer to the method of the experiment as seed spraying. This study opted to apply seeds with fertilizers and mulching

(c) The Author(s). 2018 Open Access This article is distributed under the terms of the Creative Commons Attribution 4.0 International License (http://creativecommons.org/licenses/by/4.0/), which permits unrestricted use, distribution, and 
materials as it would promote the revegetation of the landfill slope. This is supported by the findings that seed spraying can effectively recover vegetation after disturbance (Shen et al. 2007). This is also in alignment with popular practices among practitioners, exemplified by the fact that construction companies like Korea Expressway Corporation lists seed spraying as one of the most important methods for revegetation when covering constructed areas (Korean Expressway Corporation 1998).

\section{Methods}

\section{Study site}

The Sudokwon Landfill is located in Incheon, South Korea. It is the biggest sanitary landfill in the world (Song 2017). It serves the megapolis of Seoul and the neighboring Gyeonggi Province by receiving all of the household waste and most of the industrial waste. The landfill's total area is about $20,000,000 \mathrm{~m}^{2}$ and has been planned to reclaim 250 million tons of waste from 1992 to 2025 , with a possible extension of the end date currently under discussion. Reclamation site 1 had completed its waste disposal capacity in 1999, and reclamation site 2 was receiving waste as of the study period (2008). Reclamation site 1 is composed of eight layers, and site 2 had four layers. An eco-park and eco-resort have been planned for this area after the landfill closure.

\section{Species selection}

This paper selected 10 plant species to apply to the landfill soil for seed spray experiments. Each species was selected by their lifeform, features, and colors (for landscaping reasons). In selecting, perennial species were preferred as most annual species could not withstand the typical types of disturbances at the landfill (mowing and cutting). Table 1 shows the list of selected plant species and the reason why they are selected. The scientific names of the species were recorded with reference to
Lee 1989. The seed are purchased from Uri-Seed group (http://www.uriseed.com), Icheon, Korea.

\section{Experimental design}

In 2008, three areas at the Landfill were selected for seed spray experiment: (1) layer 8 of reclamation site 1 (where there is still low vegetation coverage), (2) flattened areas of layer 3 in reclamation site 2 with no vegetation because of recent construction, and (3) sloped areas of layer 4 in reclamation site 2 . At each site, $10 \mathrm{~m}$ $\times 10 \mathrm{~m}$ quadrats (three replicates) were established in early March. The top soils of each quadrat were plowed before seed application. For each of the 10 species, $100 \mathrm{~g}$ of seeds (total $1000 \mathrm{~g}$ ) was mixed with the same volume of soils and then sprayed onto the quadrats. In summer, the coverage and the number of plant individuals in each quadrat were monitored.

For germination experiment, 20 seeds for each of the 10 species were arrayed in a Petri dish for germination in a laboratory setting (three replicates). After 4 weeks, the final germination rate was determined for each species. To study the germination on the field setting, $5 \mathrm{~g}$ of seeds for each species was sprayed on $1 \mathrm{~m} \times 1 \mathrm{~m}$ quadrats in layer 4 of the reclamation site 2 on its northwest-facing slope between small trees that were planted. In summer, the coverage and number of germinated plants in each quadrat were monitored.

\section{Analysis}

For soil analysis, I collected five sub-samples (one central sampling point and four other points at different directions from the central point) at each site to be combined into one soil sample. The sampled soil was dried at $105{ }^{\circ} \mathrm{C}$ for $48 \mathrm{~h}$ to measure its water content. Its organic matter content was determined by loss on ignition (combustion at $550{ }^{\circ} \mathrm{C}$ for $4 \mathrm{~h}$ ). For bulk density and measurements, the soil was sampled with a $100-\mathrm{ml}$ soil core sampler (Eijkelkamp BV, Netherlands) and

Table 1 Features and lifeforms of the 10 selected species for landfill revegetation

\begin{tabular}{ll}
\hline Scientific name & Features \\
\hline Aster yomena Makino & Strong adaptation, representative species of the genus Aster \\
Dianthus sinensis L. & Can survive in arid, rocky area; beautiful flower; fast covering \\
Aster koraiensis Nakai & Long flowering time, good soil coverage_-prevents soil loss \\
Chrysanthemum boreale Makino & Beautiful flower, species reminiscent of fall season \\
Lythrum anceps Makino & Strong adaptation, beautiful flower \\
Potentilla chinensis Ser. & Good soil coverage_-prevents soil loss, long flowering time \\
Patrinia cabiosaefolia Fisch. & Beautiful flower, species reminiscent of fall season \\
Thalictrum aquilegifolium L. & Can survive under shade, beautiful flower \\
Pennisetum alopecuroides (L.) Spreng. & Good soil coverage—-prevents soil loss \\
Brassica campestris* & Can survive in arid, rocky areas; beautiful flower; fast covering
\end{tabular}

*Full scientific name: Brassica campestris subsp. napus var. nippo-oleifera Makino 
dried at $40{ }^{\circ} \mathrm{C}$. Its bulk density was determined as the dry weight volume/100 and porosity was calculated as 1 - (bulk density/2.60). The electrical conductivity (EC) of the soil and compost was determined by using a suspension of the soil samples in water $(20 \mathrm{~g} / 30 \mathrm{ml})$. To determine the $\mathrm{C}$ and $\mathrm{N}$ contents of the soil, three compost and samples were analyzed with an elemental analyzer (Flash EA 1112; Thermo Electron Co., USA).

To test statistically significant $(P<0.05)$ differences for comparing multiple independent groups with non-normally distributed variables, this paper employed the Kruskal-Wallis test (SAS 9.1, SAS institute, USA) to analyze the data.

\section{Results}

Table 2 shows the soil characteristics of the studied reclamation sites. As expected from the soils at reclamation sites, the soil contained very low levels of organic matter $(\mathrm{OM})$, nutrients, and moisture. Considering that agricultural soils in South Korea contain 2.5\% OM and 0.1\% total nitrogen on average (Song 2010), the landfill soils fall far below average (under $0.5 \%$ and under $0.05 \%$ respectively). Also, the bulk density was close to a hazardous level $\left(1.6 \mathrm{~g} / \mathrm{cm}^{3}\right)$, indicating soil was too compact for plants to grow.

Table 3 shows the germination rates of the selected species in a growth chamber. All species showed a higher than $50 \%$ germination rate. Brassica campestris and Dianthus sinensis showed 100\% germination. However, on the actual field site, the plants either did not germinate well or did not survive after germination (Table 4). Only Chrysanthemum boreale, Brassica campestris, and Aster yomena showed some numbers of seedlings. Dianthus sinensis showed a high germination rate, but the germinated plants did not grow well and remained at the seedling stage, resulting in the low coverage.

Table 5 shows the coverage and the number of plant individuals on the field the seeds were applied. In level (non-slope) areas like layer 8 and layer 3, the coverage and number of plant individuals were both very low to the extent that almost no effects of seed spray could be found. In contrast, in sloped areas (layer 4), Brassica campestris was able to have higher than $50 \%$ coverage. Initially, layer 4 had almost no vegetation on site, but after 1 month of seed spraying, a number of seedlings
Table 3 Germination rates in growth chamber of the 10 selected species

\begin{tabular}{ll}
\hline Scientific name & $\begin{array}{l}\text { Germination } \\
\text { rate (\%) }\end{array}$ \\
\hline Chrysanthemum boreale Makino & 80 \\
Patrinia cabiosaefolia Fisch. & 75 \\
Thalictrum aquilegifolium L. & 50 \\
Brassica campestris & 100 \\
Aster koraiensis Nakai & 60 \\
Potentilla chinensis Ser. & 60 \\
Lythrum anceps (Koehne) Makino & 80 \\
Dianthus sinensis L. & 100 \\
Pennisetum alopecuroides (L.) Spreng. & 55 \\
Aster yomena Makino & 80 \\
\hline
\end{tabular}

Values are mean of three replicates

occurred. As of October 2017, after 9 years have passed, layer 4 site still harbored average 2.1 individuals of Brassica campestris per square meter, indicating the species survived at the site.

\section{Discussion}

The purpose of the study was to test native plant species to revegetate the landfill reclamation sites as the species selected by the landfill management were all alien species (Festuca arundinacea Schreb., Silene armeria L., and Trifolium repens L.). It should be noted, however, that the native status of one of the 10 selected species has been under a small controversy (Brassica campestris subsp. napus var. nippo-oleifera Makino) as some claims that the species originate from China. This study still selected B. campestris as most authoritative works on Korean plant taxonomy do not classify the species as alien (Lee 1989). Also, B. campestris is a localized plant with an excellent capacity to revegetate (Sung et al. 2001). The other selected species in this study also had strong adaptation features or the ability to survive in arid areas that would give them better chance for survival at the landfill.

As expected, the soils were in poor conditions (see Table 2) as they had very little organic matter (OM), nutrients, and moisture well below the average values from agricultural soils in Korea. Similarly, the bulk density and electro-conductivity were at near hazardous levels $\left(1.6 \mathrm{~g} / \mathrm{cm}^{3}\right.$ and $\left.2.0 \mathrm{dS} / \mathrm{m}\right)$. The soil conditions were

Table 2 Soil characteristics of the three research sites

\begin{tabular}{|c|c|c|c|c|c|c|}
\hline Items & Organic matter & Moisture & Bulk density & Total nitrogen & Total carbon & Electro-conductivity \\
\hline Layer 8 & $0.38 \pm 0.02$ & $15.02 \pm 0.38$ & $1.43 \pm 0.01$ & $0.04 \pm 0.00$ & $0.68 \pm 0.04$ & $1.24 \pm 0.02$ \\
\hline Layer 3 (site 2) & $0.14 \pm 0.01$ & $11.8 \pm 1.21$ & $1.47 \pm 0.03$ & $0.03 \pm 0.00$ & $0.71 \pm 0.05$ & $1.34 \pm 0.02$ \\
\hline Layer 4 (site 2) & $0.12 \pm 0.01$ & $14.9 \pm 0.24$ & $1.14 \pm 0.05$ & $0.03 \pm 0.00$ & $0.64 \pm 0.03$ & $1.54 \pm 0.08$ \\
\hline
\end{tabular}

Values are mean \pm SE of five replicates. Units are $\%$, except $\mathrm{g} / \mathrm{cm}^{3}$ for bulk density and $\mathrm{dS} / \mathrm{m}$ for electro-conductivity 
Table 4 Coverage and number of seedlings of the 10 selected species in each field germination test quadrat

\begin{tabular}{lll}
\hline Scientific name & Coverage (\%) & N of seedlings \\
\hline Chrysanthemum boreale Makino & 80 & 310 \\
Patrinia cabiosaefolia Fisch. & 2 & 30 \\
Thalictrum aquilegifolium L. & 20 & 140 \\
Brassica campestris & 90 & 153 \\
Aster koraiensis Nakai & 5 & 47 \\
Potentilla chinensis Ser. & 5 & 80 \\
Lythrum anceps (Koehne) Makino & 0 & 0 \\
Dianthus sinensis L. & 9 & 300 \\
Pennisetum alopecuroides (L.) Spreng. & 0 & 0 \\
Aster yomena Makino & 40 & 211 \\
\hline
\end{tabular}

connected to slopes and aspects of the site. Layer 8 (reclamation site 1) and layer 3 (reclamation site 2) were level-surfaced with about a $5 \%$ slope, while layer 4 of reclamation site 2 was facing southwest with a $30 \%$ slope. This paper selected the southern slope as it receives the most sunlight and becomes the driest, as soil moisture is one of the most important screening factors in seed germination. Also, layer 8 and layer 3 were flattened areas that had high bulk density, while layer 4 of reclamation site 2 was a sloped area whose soil is not hardened and thus has low bulk density. Because of these conditions, layer 8 had only average $9 \%$ of vegetation coverage (average of 10 quadrats) with major species of Rudbeckia bicolor Nutt. and Festuca arundinacea Schreb which are alien seed sprayed species (Song 2010).

For seed spraying, this study used the soils at the reclamation site as the mulching material but ultimately chose not to apply fertilizers. For the initial seed spraying test, urea fertilizer with $47 \%$ nitrogen was used along with the mulching material. This turned out to be not feasible as the application site was sloped and the fertilizer, composed of round-shaped grains, easily fell off the slope. Due to the difficulties, fertilizers were not included in the actual germination and growth tests. Also during the initial test, this study experimented with mixing the soils with water and with sticky fructose syrup to reduce the seed loss. This also turned out to be unfeasible as the syrup was hardened under the site's dry condition and direct sunlight, which seemed to prevent plants from emerging above the mixture. Because of the pilot test results, the seed spray in the actual tests only included the seeds and the soils as the mulching material.

All species showed higher than $50 \%$ germination rates, with Brassica campestris and Dianthus sinensis L. showing $100 \%$ germination (Table 3). In actual fields, however, the germination rates of the species were highly varied (Table 4). Of the 10 species, only Chrysanthemum boreale, Brassica campestris, and Aster yomena showed high coverage. Dianthus sinensis L. showed a high germination rate, but the germinated plants did not grow well and remained at the seedling stage, resulting in low coverage. This shows that it is important to consider not only the germination but also the plant growth after germination. As the landfill surface is relatively dry and has low nutrient contents (Song and Lee 2010), the plants showed poor rates both in germination and seedling survivals. Although the selected species were popular species for revegetation elsewhere, the landfill has a unique condition as its soil was dug from a depth up to $100 \mathrm{~m}$ that contained almost no organic matter or nutrients. The poor soil condition was why most plants could not adapt to the condition of the landfill.

Table 5 shows the coverage and number of plants in summer after application on field. In relatively old and compact soil areas (layer 8 and layer 3), the coverage

Table 5 Coverage (\%) and number of plant individuals in quadrats in summer

\begin{tabular}{|c|c|c|c|c|c|c|}
\hline \multirow[b]{2}{*}{ Scientific name } & \multicolumn{2}{|l|}{ Layer 8} & \multicolumn{2}{|l|}{ Layer 3} & \multicolumn{2}{|l|}{ Layer 4} \\
\hline & Coverage & $N$ & Coverage & $N$ & Coverage & $N$ \\
\hline C. boreale & $0^{\mathrm{b}}$ & $0.0^{c}$ & $0^{\mathrm{b}}$ & $0.0^{c}$ & $1^{c}$ & $12.3 \pm 3.9^{c}$ \\
\hline P. cabiosaefolia & $0^{\mathrm{b}}$ & $0.0^{c}$ & $0^{\mathrm{b}}$ & $0.0^{c}$ & $0^{c}$ & $0.0^{c}$ \\
\hline T. aquilegifolium & $0^{b}$ & $0.0^{c}$ & $0^{\mathrm{b}}$ & $0.0^{c}$ & $0^{c}$ & $0.0^{c}$ \\
\hline B. campestris & $13^{\mathrm{a}}$ & $124.7 \pm 19.3^{\mathrm{a}}$ & $2^{\mathrm{a}}$ & $50.0 \pm 2.2^{a}$ & $50^{\mathrm{a}}$ & $820.0 \pm 118.5^{\circ}$ \\
\hline A. koraiensis & $0^{\mathrm{b}}$ & $0.0^{c}$ & $0^{\mathrm{b}}$ & $0.0^{c}$ & $5^{b}$ & $24.7 \pm 2.7^{c}$ \\
\hline P. chinensis & $0^{\mathrm{b}}$ & $0.0^{c}$ & $0^{\mathrm{b}}$ & $0.0^{c}$ & $0^{c}$ & $0.0^{c}$ \\
\hline L. anceps & $0^{\mathrm{b}}$ & $0.0^{c}$ & $0^{b}$ & $0.0^{c}$ & $0^{c}$ & $0.0^{c}$ \\
\hline D. sinensis & $1^{\mathrm{b}}$ & $12.3 \pm 0.9^{b}$ & $0^{\mathrm{b}}$ & $3.7 \pm 0.9^{b}$ & $4^{\mathrm{b}}$ & $3.7 \pm 0.9^{c}$ \\
\hline P. alopecuroides & $0^{\mathrm{b}}$ & $0.0^{c}$ & $0^{b}$ & $0.0^{c}$ & $0^{c}$ & $0.0^{c}$ \\
\hline A. yomena & $0^{\mathrm{b}}$ & $0.7 \pm 0.7^{c}$ & $0^{\mathrm{b}}$ & $0.0^{c}$ & $6^{b}$ & $251.0 \pm 21.9^{b}$ \\
\hline
\end{tabular}

Values are mean $( \pm \mathrm{SE})$ of three replicates. Values within a column followed by different letters are significantly different at the $p<0.05$ level $N$ number of plants 
and number of plants were very low, to an extent that almost no effects of seed spray could be detected. In contrast, sloped areas (layer 4), as it did not have the detrimental effect of soil compaction as in level areas, showed better results: Brassica campestris showed more than $50 \%$ of coverage. Layer 4 had almost no vegetation at the beginning, but after 1 month of seed spraying, a number of seedlings occurred. Dianthus sinensis and Thalictrum aquilegifolium seedlings were observed in early May. Until June, these species showed more coverage than the later period (August). After the rain season in July and hot, dry season in August, however, only Brassica campestris showed a coverage over $50 \%$ and other species decreased. Although the species showed higher coverage in germination-testing quadrats, they did not do well in actual quadrats. We can reason that, since the germination-testing quadrats were facing north, the quadrats received less sunlight and the dryness of the soils was less severe, compared to the south-facing $10 \mathrm{~m} \times 10 \mathrm{~m}$ quadrats (actual quadrats). This shows that soil moisture and plant's tolerance to drought are important factors in species selection for a landfill revegetation. Likewise, the soil moisture factor could also explain why the level-surfaced areas did not show high vegetation coverage compared to sloped areas. As flattened areas receive sunlight all day (without any shadow or any light intensity variation from the slope aspect), the areas can lack soil moisture that is important for the plants' survival. Also, as flattened areas (layer 8 and layer 3) had high bulk densities, the soils were even drier and the plants had to face more challenges for root growth (Gilman et al. 1987). This illustrates that the soils for revegetation should not be compacted to increase the soil's moisture-holding capacity and to allow a better root growth.

Brassica campestris seems to be the only effective plant for seed spray application for landfill revegetation out of the 10 species tested for this research. As its seeds are large (Nakayama et al. 2000), and a larger seed size enhances the ability to penetrate ground cover and contributes to survival rate (Reader 1993), B. campestris have better potentials for survival. The heavier seeds could also provide higher tolerance against winds that could otherwise easily remove the seeds from the application site (Nakayama et al. 2000). In contrast, the seeds of all other species were lighter-weighted, where the smallest was $0.074 \mathrm{mg}$ (Lythrum ancepts) and the heaviest was $2.7 \mathrm{mg}$ (Thalictrum aquilegifolium). As there was no seed weight data on Aster koraiensis and Brassica campestris (Nakayama et al. 2000), this study measured the weight of 100 seeds of Aster koraiensis and Brassica campestris to find average seed weight, which turned out to be $1.0 \mathrm{mg}$ for Aster koraiensis and $4.6 \mathrm{mg}$ for Brassica campestris. The result shows that Brassica campestris had the heaviest seeds among all plants, which shows why the species showed better growth at the landfill. The seed weight results also explain why two other species, Thalictrum aquilegifolium and Dianthus sinensis, showed relatively good germination and growth in spring, as the two species were the species that had the first $(2.7 \mathrm{mg}$ for Thalictrum aquilegifolium) and second (1.7 $\mathrm{mg}$ for Dianthus sinensis) heaviest seeds among the weighted species in the reference (Nakayama et al. 2000).

Another point to consider is the wind factor. The Aster, Chrysanthemum, and Pennisetum species have aristas or wings for wind dispersal, and the sprayed seeds could be dispersed across the field site. The Sudokwon Landfill is an area created by reclaiming a coastal area, and winds are very common due to the proximity to the sea. Therefore, wind tolerance would be an important factor for spraying seeds at this site, which should be considered when performing seed sprays in this landfill.

In the fall of 2017, the site (layer 4) was revisited to check whether any of the plants sprayed in 2008 were still on the site. The site, however, had undergone a fundamental change as it was landscaped with trees, Quercus acutissima Carruth and Sorbus alnifolia, indicating that the place was disturbed after the 2008 research. Because of the intervention, there was no sign of Brassica campestris, although it was not the growth season for the species. The site could not be re-checked for spring, the peak season of the Brassica campestris, because the landfill became a restricted area and opens to the public only during a fall festival period.

Pioneer species, which are usually annual plants, will also adapt well to such dry and infertile land. As the landfill usually requires and also applies species with beautiful flowers, most plant species tested are bi-annual or perennial plants with flowers. However, when it is urgent and landfill slope condition is very poor, such annual pioneer plants could be also applied. There should be a following selection of tree species for when the landfill soil becomes stable and disturbance is reduced. Maybe letting the natural succession happen in the area is one option, but another landfill such as Nanji landfill in Seoul is dominated by invasive tree species such as black locust (Robinia pseudoacacia), implying us to plant trees. As the landfill is semi-arid, the selected species should have certain resistance to drought and also should have resistance to wind. The resistance to pollution would not matter since the landfill soil is not so contaminated (Song 2010). Also biodiversity and forest layer composition should be considered. Therefore, this paper recommends eight trees including tall trees and shrubs. Pinus thunbergii Parl. and Thuja orientalis are known for their adaptation to reclaimed and semi-arid area (Kim et al. 2012). Zelkova serrata (Thunb.) Makino, Quercus acutissima Carruth., and Forsythia koreana 
(Rehd.) Nakai are recommended as they already grow well in the landfill (Song 2010). Sophora japonica L., Albizzia julibrissin Durazz, and Hibiscus syriacus L. are recommended since they already show adaptation to other closed landfills (Kim and Lee 2005). However, there should be more species to be chosen to increase biodiversity and environmental flexibility.

\section{Conclusion}

The landfill soil was in very poor condition with a high bulk density and low organic matter and nutrient contents. Among the 10 selected species for the revegetation research, only the species with larger, heavier seeds Brassica campestris, Dianthus sinensis, and Dianthus sinensis could germinate and grow on the field condition. Even among the three species, only Brassica campestris could sustain high coverage and number of individuals until after summer in the research quadrats where seeds were sprayed. The results indicate that the highly unusual condition of the reclaimed soil of the landfill (very dry with low nutrient content) allowed only the plant species with heavy seeds to adapt to the landfill environment. Also, the features of the plant species itself are important as well as the ability to survive in the arid area. Therefore, when selecting species for future revegetation of landfills or areas with a similar condition (reclaimed area), it is important to consider the plant's arid-adapted features but also other features such as seeds that are heavy in weight, have wind resistance, and can supply sufficient energy for the initial growth to survive at the harsh environment.

\section{Acknowledgements}

This research was supported by the 2017 scientific promotion program funded by the Jeju National University.

\section{Funding}

This research was supported by the 2017 scientific promotion program funded by the Jeju National University.

\section{Availability of data and materials}

The datasets supporting the conclusions of this article are included in the article.

\section{Author's contributions}

US designed and conducted the experiment and wrote the manuscript. The author read and approved the final manuscript.

\section{Ethics approval and consent to participate}

Not applicable

\section{Consent for publication}

Not applicable

\section{Competing interests}

The author declares that there are no competing interests.

\section{Publisher's Note}

Springer Nature remains neutral with regard to jurisdictional claims in published maps and institutional affiliations.
Received: 7 October 2018 Accepted: 6 November 2018

Published online: 26 November 2018

\section{References}

Anikwe MAN, Nwobodo KCA. Long term effect of municipal waste disposal on soil properties and productivity of sites used for urban agriculture in Abakaliki, Nigeria. Bioresour Technol. 2002;83:241-50.

Gilman EF, Leone IA, Flower FB. Effect of soil compaction and oxygen content on vertical and horizontal root distribution. J Environ Hortic. 1987;5:33-6.

Gottinger H-W. Economic models and applications of solid waste management. Abingdon: Routledge press; 2018.

Johannessen LM, Boyer G. Observations of solid waste landfills in developing countries: Africa, Asia, and Latin America: The World Bank; 1999.

Kim JG, Song JD, Jeon KY. Analysis of roots growth character after planting by trees species in the Saemangeum reclaimed tideland. Annual proceedings of Korean society of agricultural engineers. 0; 2012. p. 172.

Kim KD, Lee EJ. Potential tree species for use in the restoration of unsanitary landfills. Environ Manag. 2005;36:1-14.

Korean Expressway Corporation, K. Vegetating cut slope. Research report of KEC. 1998;2:122-6.

Lee TB. Illustrated flora of Korea. Seoul: Hangmoon press; 1989.

Nakayama, S., M. Inokuchi, and T. Minamitani. (2000). Seeds of wild plants in Japan. Tohoku University Press, Sendai.

Reader RJ. Control of seedling emergence by ground cover and seed predation in relation to seed size for some old-field species. J Ecol. 1993;81:169-75.

Shen Y, Yan X-I, Liang A-x, Li T-y. Study on thick-lift base material and seed spraying for side slope engineering protection. J Highw Transport Res Dev (English Edition). 2007;2:122-6.

Song U. Ecological monitoring and management of plant, soil and leachate channel in the Sudokwon landfill, Korea. Seoul: Ph.D thesis of Seoul National University; 2010.

Song U. Post-remediation use of macrophytes as composting materials for sustainable management of a sanitary landfill. Int J Phytoremediation. 2017; 19:395-401.

Song U, Lee EJ. Ecophysiological responses of plants after sewage sludge compost applications. J Plant Biol. 2010;53:259-67.

Sung Kl, Kim BW, Chung CW. Grasses and forages : optimum time of spring sowing of forage repe, oat and rye for Chinese cabbage - soiling forage double cropping system in the Taekwanryong area. Ann of anim resour sci. 2001;43:267-76.

Ready to submit your research? Choose BMC and benefit from:
- fast, convenient online submission
- thorough peer review by experienced researchers in your field
- rapid publication on acceptance
- support for research data, including large and complex data types
- gold Open Access which fosters wider collaboration and increased citations
- maximum visibility for your research: over 100M website views per year
At BMC, research is always in progress.
Learn more biomedcentral.com/submissions

